\title{
Function of BID - a Molecule of the bcl-2 Family - in Ischemic Cell Death in the Brain
}

\author{
Nikolaus Plesnila ${ }^{a}$ Sandra Zinkel ${ }^{b}$ Sepideh Amin-Hanjani ${ }^{a}$ Jianhua Qiu ${ }^{a}$ \\ Stanley J. Korsmeyer ${ }^{b}$ Michael A. Moskowitz ${ }^{a}$ \\ a Stroke and Neurovascular Regulation Laboratory, Massachusetts General Hospital, Harvard Medical School, \\ Charlestown, Mass., and bepartments of Pathology and Medicine, Dana-Farber Cancer Institute, \\ Harvard Medical School, Howard Hughes Medical Institute, Boston, Mass., USA
}

\section{Key Words}

Cerebral ischemia - Apoptotic cell death - Cytochrome c release $\cdot$ BID $\cdot$ Knock-out mice

\begin{abstract}
Mitochondrial mechanisms, particularly the release of cytochrome c, play a role in the death of nerve and glial cells in cerebral ischemia. We have currently investigated whether BID, a proapoptotic molecule of the bcl-2 family and promoter of the release of cytochrome $c$ is expressed in the brain, activated by cerebral ischemia in vivo, and contributes to ischemic cell death. We found BID in the cytosol of mouse brain and of primary cultured mouse neurons and showed that neuronal BID is a substrate for caspase 8. BID was cleaved in vivo $4 \mathrm{~h}$ after transitory occlusion of the middle cerebral artery. Further, $\mathrm{BID}^{-/-}$mice had a significant attenuation of infarction $(-67 \%)$ and significantly lower release of cytochrome c $(-41 \%)$. The findings indicate that the proapoptotic molecule BID may contribute to the demise of nerve cells from cerebral ischemia by release of cytochrome $c$ and activation of caspase.
\end{abstract}

Copyright $@ 2002$ S. Karger AG, Basel

\section{Introduction}

Programmed cell death is a feature of chronic and acute neurodegenerative diseases including Alzheimer's and Huntington's disease, amyotrophic lateral sclerosis (ALS), and stroke $[1,2]$. It is mediated, in part, by caspases, a family of cysteine proteases that cleave and disassemble proteins essential for cell survival [3]. Caspases are activated during cerebral ischemia [4-6], and ischemic cell death is significantly attenuated by caspase inhibition [7] or caspase gene deletion [8].

The sequence of events leading to caspase activation has been well characterized in non-neuronal cells [9]. In these cells, BID, a 22-kDa cytosolic member of the Bcl-2 family of proapoptotic proteins [10] provides one mechanism by which TNF/Fas family death receptor activation is linked to downstream events [11]. These death receptors activate caspase 8 , which cleaves BID to its truncated active form (tBID; $15 \mathrm{kDa}$ )[12]. tBID targets the outer mitochondrial membrane and induces conformational changes in BAK and BAX [13] and by so doing, triggers cytochrome c release into the cytosol [14]. There cytochrome $\mathrm{c}$ together with APAF-1 and caspase 9 form the apoptosome complex, which results in activation of cas-

\begin{tabular}{ll}
\hline KARGER & ( ) 2002 S. Karger AG, Basel \\
$\begin{array}{l}\text { Fax +41 61 306 1234 } \\
\text { E-Mail karger@karger.ch } \\
\text { www.karger.com }\end{array}$ & $\begin{array}{l}\text { Accessible online at: } \\
\text { www.karger.com/journals/esr }\end{array}$
\end{tabular}

Nikolaus Plesnila, MD

University of Munich, Institute for Surgical Research

Marchioninistrasse 27

D-81377 München (Germany)

Tel. +49 897095 4352, Fax +49897095 4353, E-Mail plesnila@icf.med.uni-muenchen.de 
pase 3 and other effector caspases and ultimately cause cell death [15]. The importance of BID in death receptor mediated programmed cell death and in amplification of upstream cell death signals is demonstrated by the fact that BID knockout mice are strongly resistant to death receptor induced hepatocellular apoptosis [16].

Very little is known about BID expression and its role in brain, or in fact, whether a similar death pathway involving BID exists in neurons. However, expression of cell surface death receptors of the TNF/Fas family [1719], cleavage of caspase 8 [5] and caspase 3 [6], and release of cytochrome c from mitochondria [20], have all been described individually in ischemia. Given these similarities, we hypothesized that BID may figure as a mediator upstream of mitochondria in neuronal death after cerebral ischemia. To explore this hypothesis, we used a well-characterized model of ischemic cell death (middle cerebral artery occlusion, MCAo). We determined whether BID knockout mice were protected against ischemia, and examined the relationship between the presence of activated BID (tBID) and cytochrome $\mathrm{c}$ release in adult mouse brain.

Part of the original findings of this study have already been published elsewhere [21].

\section{Methods}

\section{Cytosolic and Mitochondrial Proteins}

Tissues from adult C57Bl/6 mice (20-25 g) were homogenized in 10 volumes of hypertonic buffer [22]. Supernatants containing cytosolic proteins were isolated by centrifugation at 20,000 g. tBID was enriched by immunoprecipitation $(150 \mu \mathrm{g}$ protein incubated with anti-BID/tBID antibody at 1:500 dilution over night). All procedures were performed at $4^{\circ} \mathrm{C}$.

\section{Western Blot}

10-20 $\mu \mathrm{g}$ protein/lane were separated and blotted as previously described [23]. The blot was probed with anti-Bid (rabbit polyclonal, 1:1,000), or anti-cytochrome c (clone 7H8.2C12, 1:200, BD PharMingen, Franklin Lakes, N.J., USA) at $4^{\circ} \mathrm{C}$ overnight. Membranes were then exposed to horseradish-peroxidase-conjugated anti-rabbit $\mathrm{IgG}$ for $1 \mathrm{~h}$. Antibody binding was detected using the ECL system (Amersham, Arlington Heights, IL). Equal protein loading of gels was assured by Coomassie Blue or $\alpha$-tubulin staining. Relative optical density of protein bands was quantitated by using the Bio-Rad MultiAnalist Version 1.0

\section{Transgenic Mice}

BID-deficient mice $\left(\mathrm{BID}^{-/-}\right)$were generated as previously described [16] and backcrossed 7-8 generations into its $\mathrm{C} 57 \mathrm{Bl} / 6$ background strain. BID ${ }^{-/-}$mice were born at the expected Mendelian frequency and showed no apparent developmental abnormalities. As controls wild type animals $\left(\mathrm{BID}^{+/+}\right)$from the same litter ('littermates') were used for all experiments. The macro- and microscopic brain morphology of uninjured BID ${ }^{-/-}$mice did not differ from wild type controls. Only male mice matched for age (6 weeks) and weight (20-25 g) were used for experiments.

\section{Transitory Focal Cerebral Ischemia}

Cerebral ischemia was induced by an intraluminal filament as previously described [24]. Successful occlusion and reperfusion was demonstrated by Laser-Doppler flowmetry (PF2B; Perimed, Stockholm, Sweden) in each animal. Functional outcome was assessed on a 5 -point scale $(0=$ no deficit, $1=$ weakness of the contralateral forepaw, 2 = circling, 3 = loss of righting reflex, $4=$ no motor activity).

\section{Cytochrome c Assay}

Cytochrome $\mathrm{c}$ in cytosolic fractions of brain homogenates was measured by an ELISA system specific for mouse cytochrome c (R\&D Systems, Minneapolis, Minn., USA). Homogenates were prepared from an equivalent lesioned area (striatum) in both strains. Results are expressed as ng cytochrome c/mg protein. Values obtained from the non-ischemic hemisphere were subtracted from the values for the ischemic hemisphere in order to obtain a measure for cytochrome $\mathrm{c}$ release specific to ischemia. The cytosolic origin of the samples was proven by the fact that cytochrome oxidase, a mitochondrial protein, was not detected in these brain fractions (data not shown).

\section{Statistical Analysis}

Data are presented as mean \pm SEM. All statistical analyses were made with the SigmaStat 2.0 software package (Jandel Scientific, Erkrath, Germany). For comparison between WT and BID ${ }^{-/}$groups the Mann-Whitney Rank Sum test was used. $\mathrm{p}<0.05$ was considered statistically significant.

\section{Results}

\section{Expression of BID in the Brain}

We characterized BID expression by demonstrating its presence in brain. A 22-kDa band corresponding to BID was observed in murine whole brain homogenates $(n=2)$. The 22-kDa band was absent in homogenates from BID ${ }^{-/}$ mice $(n=2$; fig. 1$)$.

\section{Activation of BID after Cerebral Ischemia}

In wild type mice, we demonstrated by Western Blot analysis that BID was cleaved to its $15-\mathrm{kDa}$ active fragment (tBID) $2 \mathrm{~h}$ following $2 \mathrm{~h}$ of middle cerebral artery occlusion (fig. 2).

\section{Protection in BID ${ }^{-/-}$Mice after Focal Cerebral \\ Ischemia}

In order to investigate if BID mediates ischemic cell death, $\mathrm{BID}^{-/-}$and wild-type littermate mice were subjected to $30 \mathrm{~min}$ of middle cerebral artery occlusion and $48 \mathrm{~h}$ of reperfusion. Blood flow distal to the occlusion dropped below $20 \%$ in the two groups and returned to 


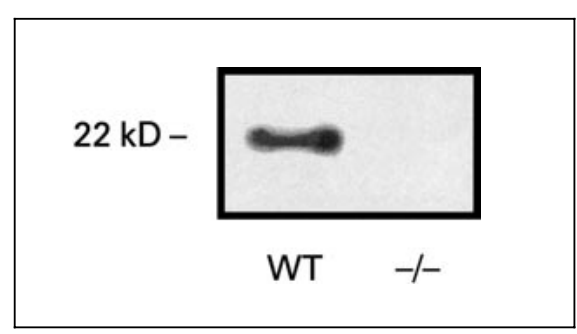

Fig. 1. $B I D$ is expressed in mouse brain. Mouse $(\mathrm{C} 57 \mathrm{~B} / 6)$ brain homogenate was probed for BID with a rabbit polyclonal antibody (Western blotting). A 22-kDa band was detected which corresponds to recombinant mouse BID [12]. This band was not detected in brain homogenate from BID ${ }^{-/-}$mice $(\mathrm{n}=3)$. From [21].

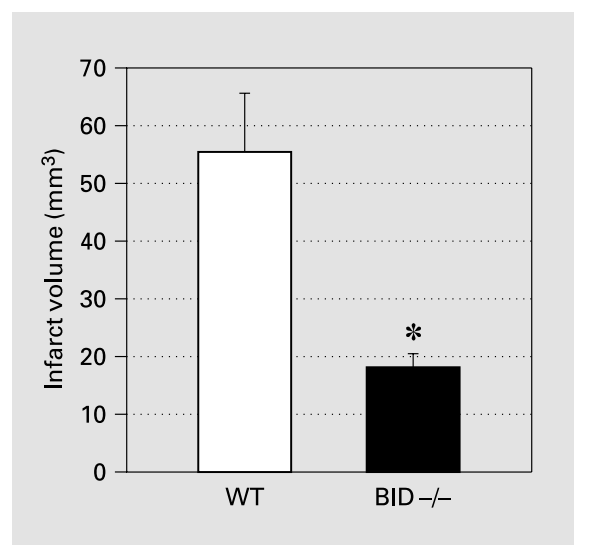

Fig. 3. Ischemic damage is reduced in $\mathrm{BID}^{-/-}$mice. Infarct volume was reduced by $67 \%$ in $\mathrm{BID}^{-/-}$mice as compared to wild type mice $(\mathrm{n}=8$ per group; $* \mathrm{p}<0.01)$ after 30 min middle cerebral artery occlusion and $48 \mathrm{~h}$ reperfusion. From [21].

pre-occlusion levels after recirculation. The mean infarct volume was $67 \%$ smaller in BID $^{-/-}$mice $(55.5 \pm 29.0$ $\mathrm{mm}^{3}$ and $18.3 \pm 6.4 \mathrm{~mm}^{3}$ in wild type and mutant, respectively; $\mathrm{n}=8$ per group; $\mathrm{p}<0.002$; fig. 3 ). In wild type animals, the lateral striatum and the adjacent cerebral cortex showed extensive ischemic injury, while the cortex was spared in $\mathrm{BID}^{-/-}$mice. Animals had only slight neurological deficits 24 and $48 \mathrm{~h}$ after ischemia $(0.4 \pm$ 0.2 ) and there was no difference between groups. Following ischemia, brain edema was minimal and did not differ between groups: the volumes of the ischemic hemispheres were $102 \pm 3 \%$ and $104 \pm 5 \%$ of the contralateral hemispheres in wild type and mutants, respectively.

Role of BID in Ischemic Cell Death

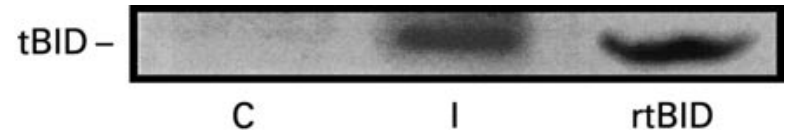

Fig. 2. BID cleavage after focal ischemia. Two hours after $2 \mathrm{~h}$ of MCAo, brain homogenates from the ischemic (I) and contralateral hemisphere were subjected to immunoprecipitation with an antitBID antibody followed by Western blot analysis. tBID obtained by incubation of recombinant BID with recombinant active caspase 8 was used as positive control (tBID) $(\mathrm{n}=2)$. From [21].

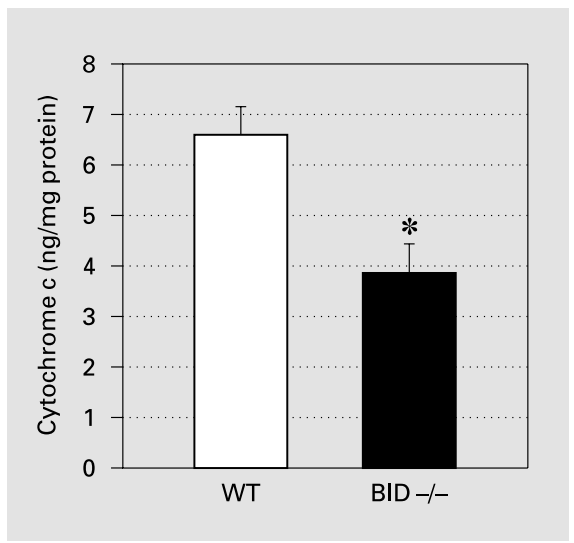

Fig. 4. Cytochrome $\mathrm{c}$ release after focal ischemia. Following ischemia, $41 \%$ less cytochrome $\mathrm{c}$ was measured by ELISA in the cytosol of $\mathrm{BID}^{-/-}$mice $(\mathrm{n}=4)$ as compared to wild type littermates $(\mathrm{n}=4$; $* \mathrm{p}<0.03)$. From [21].

\section{Cytochrome C Release in BID ${ }^{-/}$Mice after Focal Cerebral Ischemia}

Next we investigated whether BID was part of apoptotic signaling pathways in vivo by comparing the levels of cytosolic cytochrome $\mathrm{c}$ in homogenates of ischemic brains from wild type and $\mathrm{BID}^{-/-}$mice subjected to $2 \mathrm{~h}$ of MCAo. A significant reduction (-41\%) was found in the mutant brain by an ELISA method $(3.9 \pm 1.1$ vs. $6.6 \pm$ $1.1 \mathrm{ng} / \mathrm{mg}$ protein for mutant and wild type, respectively, $\mathrm{n}=4 ; \mathrm{p}<0.03$; fig. 4). As an important precondition to interpreting these experiments, we verified that there were no pre-morbid differences between wild type and $\mathrm{BID}^{-/-}$groups in brain volume, vascular anatomy, resting

Eur Surg Res 2002;34:37-41 
absolute blood flow $(209 \pm 24$ vs. $220 \pm 17 \mathrm{ml} / 100 \mathrm{~g} / \mathrm{min}$ in wild type and mutants, respectively), or overt behavior.

\section{Phenotypes of BID ${ }^{-/-}$Mice}

Macroscopically we observed no differences in brain size or weight, or differences in histology (HE and cresyl violet) between mutants and wild type strains. There were no differences in numbers of neurons when other sites like superior cervical ganglia and facial nerve nucleus were counted (Korsmeyer, pers. commun.). The $\mathrm{BID}^{-/-}$mice show no other obvious abnormal neuronal phenotypes and the development of neuronal lineages is apparently normal [16].

\section{Discussion}

We established that BID is a critical mediator of ischemic cell death within the central nervous system. We observed reduced ischemic brain injury in mice with deletion of the BID gene (fig. 3). We also found BID cleavage in ischemic brain after ischemia (fig. 2). Treatment with caspase inhibitors attenuated cell death and tissue injury after in vivo and in vitro ischemia [21,22]. Hence, BID as well as caspases are critical cell death mediators of ischemic brain injury.

In non-neuronal cells, caspase activation can occur via a sequence of events known as type II death receptor signaling [25], in which stimulation of death receptors activates caspase 8 . Caspase 8 in turn cleaves BID to tBID. After migration to the mitochondrial membrane and interaction with Bax tBID causes cytochrome $\mathrm{c}$ release from mitochondria, which results in the activation of caspase 3 and other caspases. Our data show that the molecular pathway for ischemic cell death in neurons resembles the type II pathway. Caspase 8 is constitutively expressed in brain and focal ischemia in vivo triggers activation of caspase 8 [5]. We have evidence that caspase 8 cleaved BID to tBID from brain homogenates [21]. Taken altogether, it is likely that caspase 8 mediates BID cleavage in the CNS as it is the cysteine protease with the strongest BID-cleaving activity [12].

Regarding cytochrome $\mathrm{c}$ release, BID acts upstream of both cytochrome $\mathrm{c}$ release and caspase- 3 activation in non-neuronal cells [12]. In the CNS, we found attenuated cytochrome $\mathrm{c}$ release in ischemic striatum from $\mathrm{BID}^{-/-}$ mice following middle cerebral artery occlusion (fig. 4) and less caspase 3 activation after oxygen glucose deprivation in BID $^{-/-}$cortical neurons [21]. In addition, BID deletion reduces cytochrome c release, and protects against fas-mediated liver injury [16] and against ischemia-induced CNS injury in vivo as shown in our present study.

Despite strong evidence linking BID to pore formation in the outer mitochondrial membrane, and to cytosolic release of cytochrome c, cytochrome c release was not completely abrogated in cells and tissues of BID ${ }^{-/-}$mice (fig. 4). Release was apparently not caused by rupture of mitochondrial membranes as we did not detect cytochrome oxidase, a mitochondrial protein, in cytosolic fractions at the same time (not shown). Our data suggest that BID is not the sole mechanism for cytochrome c release after cerebral ischemia. Other mechanisms and molecules may contribute to the release process such as unique mechanisms related to $\mathrm{Bax}, \mathrm{Bad}, \mathrm{Bcl}-2, \mathrm{Bcl}-\mathrm{X}_{\mathrm{L}}$, oxygen radicals, MnSOD, or opening of the mitochondrial permeability transition [26-29]. Furthermore, BCL2 , and BCL-w modulate cytochrome $\mathrm{c}$ release and, for example, an increase in their expression could protect tissues from injury during ischemia [30, 31]. BID and other mechanisms may also effect survival in non-neuronal cell types (e.g., astrocytes, endothelial cells, microglia) which were spared in ischemic BID $^{-/-}$mouse brain. Further work is necessary to clarify this point. Nevertheless, the results generated using BID $^{-/-}$mice convincingly demonstrate a prominent role for BID in acute CNS injury. Future strategies using gene therapy including dominantnegative or anti-sense approach to eliminate BID may be utilized to determine if they may help reduce brain injury after cerebral ischemia.

In summary, BID promotes cell death in the brain following focal cerebral ischemia. Because BID is strategically located upstream of mitochondria and caspase 3 processing [32], BID presents an attractive therapeutic target for central nervous system diseases in which apoptotic cell death is prominent.

\section{Acknowledgments}

This work was supported by grants from the Deutsche Forschungsgemeinschaft (Pl 249/5-1 to NP) and the National Institutes of Health (NS10828 and NS374141-02 to MAM).
40

Eur Surg Res 2002;34:37-41
Plesnila/Zinkel/Amin-Hanjani/Qiu/ Korsmeyer/Moskowitz 


\section{References}

1 Mattson MP: Apoptosis in neurodegenerative disorders. Nature Rev Mol Cell Biol 2000;1: 120-129.

2 Yuan J, Yankner BA: Apoptosis in the nervous system. Nature 2000;407:802-809.

3 Robertson GS, Crocker SJ, Nicholson DW, Schulz JB: Neuroprotection by the inhibition of apoptosis. Brain Pathol 2000;10:283-292.

4 Krajewski S, Krajewska M, Ellerby LM, Welsh K, Xie Z, Deveraux QL, Salvesen GS, Bredesen DE, Rosenthal RE, Fiskum G, Reed JC: Release of caspase-9 from mitochondria during neuronal apoptosis and cerebral ischemia. Proc Natl Acad Sci USA 1999;96:5752-5757.

5 Velier JJ, Ellison JA, Kikly KK, Spera PA, Barone FC, Feuerstein GZ: Caspase- 8 and caspase- 3 are expressed by different populations of cortical neurons undergoing delayed cell death after focal stroke in the rat. J Neurosci 1999; 19:5932-5941.

6 Namura S, Zhu J, Fink K, Endres M, Srinivasan A, Tomaselli KJ, Yuan J, Moskowitz MA: Activation and cleavage of caspase- 3 in apoptosis induced by experimental cerebral ischemia. J Neurosci 1998;18:3659-3668.

7 Hara H, Friedlander RM, Gagliardini V, Ayata C, Fink K, Huang Z, Shimizu-Sasamata M, Yuan J, Moskowitz MA: Inhibition of interleukin 1 beta converting enzyme family proteases reduces ischemic and excitotoxic neuronal damage. Proc Natl Acad Sci USA 1997;94: 2007-2012.

8 Schielke GP, Yang GY, Shivers BD, Betz AL: Reduced ischemic brain injury in interleukin-1 beta converting enzyme-deficient mice. J Cereb Blood Flow Metab 1998;18:180-185.

9 Strasser A, O'Connor L, Dixit VM: Apoptosis signaling. Annu Rev Biochem 2000;69:217245.

10 Wang K, Yin XM, Chao DT, Milliman CL, Korsmeyer SJ, BID: A novel BH3 domain-only death agonist. Genes Dev 1996;10:2859-2869.

11 Nagata S: BIDdable death. Nat Cell Biol 1999; 1:E143-E145

12 Li H, Zhu H, Xu CJ, Yuan J: Cleavage of BID by caspase 8 mediates the mitochondrial damage in the Fas pathway of apoptosis. Cell 1998; 94:491-501.

13 Zha J, Weiler S, Oh KJ, Wei MC, Korsmeyer SJ: Posttranslational N-myristoylation of BID as a molecular switch for targeting mitochondria and apoptosis. Science 2000;290:17611765
14 Wei MC, Lindsten T, Mootha VK, Weiler S, Gross A, Ashiya M, Thompson CB, Korsmeyer SJ: tBID, a membrane-targeted death ligand, oligomerizes BAK to release cytochrome c. Genes Dev 2000;14:2060-2071.

15 Zou H, Li Y, Liu X, Wang X: An APAF-1.cytochrome c multimeric complex is a functional apoptosome that activates procaspase-9. J Biol Chem 1999;274:11549-11556.

16 Yin XM, Wang K, Gross A, Zhao Y, Zinkel S, Klocke B, Roth KA, Korsmeyer SJ: BID-deficient mice are resistant to Fas-induced hepatocellular apoptosis. Nature 1999;400:886-891.

17 Martin-Villalba A, Herr I, Jeremias I, Hahne M, Brandt R, Vogel J, Schenkel J, Herdegen T, Debatin KM: CD95 ligand (Fas-L/APO-1L) and tumor necrosis factor-related apoptosisinducing ligand mediate ischemia-induced apoptosis in neurons. J Neurosci 1999;19: 3809-3817.

18 Harrison DC, Roberts J, Campbell CA, Crook B, Davis R, Deen K, Meakin J, Michalovich D, Price J, Stammers M, Maycox PR: TR3 death receptor expression in the normal and ischaemic brain. Neuroscience 2000;96:147-160.

19 Rosenbaum DM, Gupta G, D'Amore J, Singh M, Weidenheim K, Zhang H, Kessler JA: Fas (CD95/APO-1) plays a role in the pathophysiology of focal cerebral ischemia. J Neurosci Res 2000;61:686-692.

20 Fujimura M, Morita-Fujimura Y, Murakami K, Kawase M, Chan PH: Cytosolic redistribution of cytochrome $\mathrm{c}$ after transient focal cerebral ischemia in rats. J Cereb Blood Flow Metab 1998;18:1239-1247.

21 Plesnila N, Le DA, Zinkel S, Amin-Hanjani S, Qiu J, Chiarugi A, Thomas SS, Korsmeyer SJ, Moskowitz MA: BID mediates cell death after acute neurodegeneration induced by stroke and oxygen-glucose deprivation. Proc Natl Acad Sci USA 2001;98:15318-15323.

22 Chiarugi A and Moroni F: Effects of mitochondria and o-methoxybenzoylalanine on 3-hydroxyanthranilic acid dioxygenase activity and quinolinic acid synthesis. J Neurochem 1999; 72:1125-1132.

23 Matsushita K, Wu Y, Qiu J, Lang-Lazdunski L, Hirt L, Waeber C, Hyman BT, Yuan J, Moskowitz MA: Fas receptor and neuronal cell death after spinal cord ischemia. J Neurosci 2000;20: 6879-6887.
24 Huang Z, Huang PL, Panahian N, Dalkara T, Fishman MC, Moskowitz MA: Effects of cerebral ischemia in mice deficient in neuronal nitric oxide synthase. Science 1994;265:18831885

25 Scaffidi C, Fulda S, Srinivasan A, Friesen C, Li F, Tomaselli KJ, Debatin KM, Krammer PH, Peter ME: Two CD95 (APO-1/Fas) signaling pathways. EMBO J 1998; 17:1675-1687.

26 Fujimura M, Morita-Fujimura Y, Noshita N, Sugawara T, Kawase M, Chan PH: The cytosolic antioxidant copper/zinc-superoxide dismutase prevents the early release of mitochondrial cytochrome $\mathrm{c}$ in ischemic brain after transient focal cerebral ischemia in mice. J Neurosci 2000;20:2817-2824.

27 Siesjo BK, Elmer E, Janelidze S, Keep M, Kristian T, Ouyang YB, Uchino H: Role and mechanisms of secondary mitochondrial failure. Acta Neurochir Suppl (Wien) 1999;73:7-13.

28 Fiskum G, Murphy AN, Beal MF: Mitochondria in neurodegeneration: Acute ischemia and chronic neurodegenerative diseases. J Cereb Blood Flow Metab 1999;19:351-369.

29 Springer JE, Azbill RD, Nottingham SA, Kennedy SE: Calcineurin-mediated BAD dephosphorylation activates the caspase- 3 apoptotic cascade in traumatic spinal cord injury. J Neurosci 2000;20:7246-7251.

30 Martinou JC, Dubois-Dauphin M, Staple JK, Rodriguez I, Frankowski H, Missotten M, Albertini P, Talabot D, Catsicas S, Pietra C: Overexpression of $\mathrm{BCL}-2$ in transgenic mice protects neurons from naturally occurring cell death and experimental ischemia. Neuron 1994;13:1017-1030.

31 Yan C, Chen J, Chen D, Minami M, Pei W, Yin XM, Simon RP: Overexpression of the cell death suppressor Bcl-w in ischemic brain: Implications for a neuroprotective role via the mitochondrial pathway. J Cereb Blood Flow Metab 2000;20:620-630.

32 Fink K, Zhu J, Namura S, Shimizu-Sasamata M, Endres M, Ma J, Dalkara T, Yuan J, Moskowitz MA: Prolonged therapeutic window for ischemic brain damage caused by delayed caspase activation. J Cereb Blood Flow Metab 1998;18:1071-1076. 